\title{
A proposal of multiplace hyperbaric chamber for animal experimentation and veterinary use ${ }^{1}$
}

\author{
Uma proposta de câmara hiperbárica para uso em animal de experimentação e uso \\ veterinário
}

\author{
Fabrício Valandro RechI, Djalma José Fagundes ${ }^{\mathrm{II}}$, Reginaldo Hermanson ${ }^{\mathrm{III}}$, Henri Chaplin Rivoire ${ }^{\mathrm{IV}}$, Anna Luiza Negrini \\ Fagundes ${ }^{\mathrm{V}}$ \\ ${ }^{\mathrm{I}} \mathrm{MD}$, Visitant Researcher of Integrate Regional University of Alto Uruguai and Missões - Campus of Erechim (RS), Brazil. \\ ${ }^{\text {II }} \mathrm{MD}, \mathrm{PhD}$, Associate Professor of Surgery, Division of Operative Technique and Experimental Surgery, Department of Surgery, UNIFESP, \\ Brazil. \\ III Chemical Engineer, São Paulo, Brazil. \\ Iv MD, PhD, Associate Professor, Head of Department of Surgery, Rio Grande Federal Foundation University (FURG), Brazil. \\ ${ }^{v}$ Medical student, Santo Amaro University (UNISA), São Paulo, Brazil.
}

\begin{abstract}
Purpose: To develop a project of hyperbaric chamber that allows its safe and reliable use in veterinary and animal experimentation. Methods: Based on the technical specifications for the construction of hyperbaric chambers for human beings, it has been developed a design of a chamber with dimensions and characteristics for the use of a midsize animal, (dog or pig), as well as a multiple chamber for the use in small animals (mice, rats, hamsters, rabbits or cats). The technical specifications allowed that the chamber could be used both for veterinary use and for use in experiments on Health Sciences. Results: A chamber with the following characteristics was built: ASTM A36 steel for the manufacture of the master cylinder and rear cover; front door built in 5052 aluminum; internal diameter of $50.5 \mathrm{~cm}$ and $83.0 \mathrm{~cm}$ in length; weight $160 \mathrm{Kg}$ and internal area of $150 \mathrm{~cm}^{3}$; internal space to accommodate 2 acrylic baskets; $150 \mathrm{~mm}$ high, $280 \mathrm{~mm}$ wide and $690 \mathrm{~mm}$ in length. It was capable of supporting a maximum of hydrostatic pressure test of 3.0 to 4.0 BAR ACT and maximum working pressure of 2.0 BAR or 3.0 ACT; equipped with security devices and valves that triggers with load of 2.2 BAR or 3.2 ACT. Tests for engineering and biological use on animals showed the effectiveness of the device. Conclusion: The development of the project enabled the construction of a hyperbaric chamber with security features and reliability comparable to those required by the legal and technical specifications of a hyperbaric chamber human use.
\end{abstract}

Key words: Hyperbaric Oxygenation. Models, Animal. Veterinary Medicine

\section{RESUMO}

Objetivo: Desenvolver um projeto de câmara hiperbárica que permita o seu uso seguro e confiável em veterinária e em animais de experimentação de pequeno e médio porte. Métodos: Baseados em especificações técnicas de construção de câmaras hiperbáricas de seres humanos, foi desenvolvido uma adaptação de projeto de uma câmara com dimensões e características para uso em animal de médio porte (cão ou porco), assim como câmara múltipla para animais de pequeno porte (camundongos, ratos, hamsters, coelhos ou gatos). $\mathrm{O}$ atendimento às especificações técnicas deve permitir a sua utilização tanto para uso veterinário quanto para uso em experimentação em Ciências da Saúde. Resultados: Uma câmara com as seguintes características foi construída: aço ASTM A36 para a confecção do cilindro principal e tampo traseiro, tampo frontal (porta) construído em alumínio 5052, diâmetro interno de $50,5 \mathrm{~cm}$ e $83,0 \mathrm{~cm}$ de comprimento; peso de $160 \mathrm{Kg}$ e espaço interno de $150 \mathrm{~cm}^{3}$; espaço para acomodar 2 cestas de acrílico de $150 \mathrm{~mm}$ de altura, 280mm de largura e 690mm de comprimento; capacidade para suportar um máximo de pressão hidrostática teste de 3,0BAR ou 4,0 ACT e uma pressão máxima de trabalho de 2,0 BAR ou 3,0 ACT; equipado com dispositivos e válvulas de segurança que disparam com carga de 2,2 BAR ou 3,2 ACT. Os testes de engenharia e de uso biológico com animais mostraram a efetividade do equipamento. Conclusão: $O$ desenvolvimento do projeto permitiu a confecção de uma câmara hiperbárica com características de segurança e confiabilidade comparável às exigidas pelas especificações técnicas e legais de uma câmara para tratamento hiperbárico.

Descritores: Oxigenação Hiperbárica. Modelo Animais. Medicina Veterinária

${ }^{1}$ Research performed at Surgery and Experimentation Pos-Graduate Program, Operative Technique and Experimental Surgery Division, Department of Surgery, Federal University of São Paulo (UNIFESP), Brazil. 


\section{Introduction}

Hyperbaric oxygen (HBO) is a medical therapeutic modality that offers pure oxygen in pressurized environment two or three absolute atmospheres above the atmospheric pressure $^{1}$. The hyperbaric chambers (mono or multiplace) are equipments especially built to support the higher pressures using compressed air or medicinal oxygen ${ }^{2}$.

The dispersion of the high oxygen concentrations in the corporal liquids, especially in the plasma has shown useful effect in numerous pathological circumstances ${ }^{3-11}$. Initially, the chambers had their spreading and effectiveness related to the illnesses associated to the decompression of divers, asthma and pulmonary tuberculosis ${ }^{12}$. Later, was extended to primary treatment of gas embolism, poisoning by carbon monoxide or cyanides, decompression illness and some kinds of anemia. Also, it showed effectiveness on treatment of other diseases, e.g. clostridium infection, mionecrosis, compartment syndrome after crushing trauma, healing of wounds, necrotizing infections of soft tissue, osteomyelite with no response to the conventional treatment, abscess of liver and spleen or others in places of difficult access to perform the surgical drainage, injuries by ionizing irradiation, skin grafts and other tissues compromised by ischemia and/or infection and skin burnings ${ }^{13}$.

In spite of these current treatment ${ }^{13}$, controversies about its action mechanism on physiopathology of these diseases persist. In addition, there are not consensuses about the session's length and its frequency, as well as about the adverse effects.

The research in HBO, using experimentation animals, is a priority for the systematic and scientific study of its physiologic and pathologic principles. The equipment for $\mathrm{HBO}$ requires guarantee of constant and regular pressurization, regular and effective oxygenation for its safe use. HBO chamber for pet or experimental animals it is not commercially available in Brazil. Thus, based on the International recommendations and on the Brazilian regulating agencies for $\mathrm{HBO}$ proceedings and with an engineering company partnership it was built and tested a hyperbaric chamber that aimed to the experimental use and with extension of application to the veterinary medicine ${ }^{14-17}$.

The proposal of this work is to present the main features of a hyperbaric chamber project and its development for special use in small and midsize laboratory animals, observing the same standard rules of trust and safety of the chambers for human use.

\section{Methods}

Initially, was identified the Brazilian ${ }^{14,15}$ and International $^{16-18}$ rules on HBO. A research in the biomedical database (Pubmed, Medline, Lilacs and Scielo) was performed in order to identify other similar projects ${ }^{19-23}$. The engineering blueprints and drawings were done in accordance to allow a multiplace chamber that could contain a variable number of experimental animals of small size (mice, rats, hamsters, guinea pigs) or bigger ones (rabbits, mini pigs, cats.) Moreover, a multiple chamber could be used as a monoplace mode for a dog or a pig.

The engineer partner and the technicians, with professional knowledge and experience in the area, made several drawings (Figure 1 - right) and different attempts until to reach the definitive project that attended to the rules of $\mathrm{HBO}$ and the needs of the biological partners.

\section{The legal specifications required}

a) Brazilian rules: Brazilian National Metrology Institute, Industrial Standardization and Quality (Instituto Nacional de Metrologia, Normalização e Qualidade Industrial) ${ }^{14}$ and standard rule NR13 (Norma Reguladora - NR13) from Brazilian Ministry of Labor (Ministério do Trabalho) ${ }^{15}$.

b) International Laws ${ }^{16-18}$ : American Society of Mechanical Engineers (ASME) ASME Section VIII - Div. 1 ASME UW-12 Type 2 ASME UW-12 D ASME UW-12 C ASME UG99 and National Fire Protection Association (NFPA).
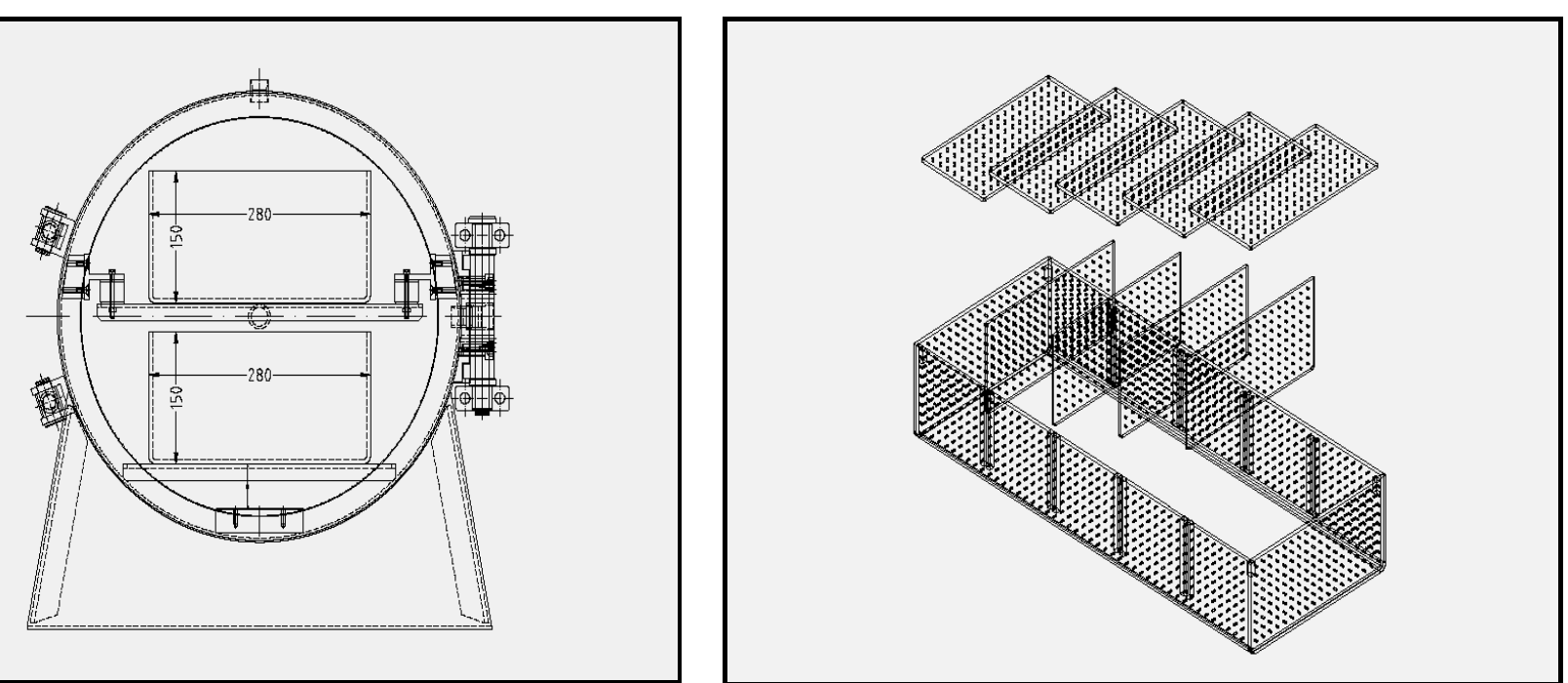

FIGURE 1 - Blueprint of the first phase - frontal view of the project with the specifications techniques of the Hyperbaric Chamber (right). Schematic drawing of the acrylic drawers (left) 


\section{Mechanical engineering}

The project was elaborated according to the rules for pressuring vases Category $\mathrm{C}$ - Classroom BI, having as a project reference the Code ASME section VIII - Division $1^{16}$. The steel used was ASTM A36 for the hoof and for its deep cover, aluminum 5052 for its frontal cover (door), gloves in stainless steel and valves in brass.

\section{Civil engineering}

The laboratory room must have at least $1,70 \mathrm{~m}$ of length, $1,16 \mathrm{~m}$ of width and $0,74 \mathrm{~m}$ of height, with air-conditioning, and without direct incidence of solar rays. The equipment must be located in a place which allows easy access for inspections and repairs. The electric feeding has to be adjusted to $110 / 220$ volts. Special attention must be given to the electric isolation system, which must have resistance smaller than 5 Ohms. The oxygen supply must be with a minimum pressure of 3.5 bars. The ducts of the exhaustion system are expected to reach the external area of the building, always far from electric equipment, displayed flames or any another combustible material in the area.

\section{Biological requirement}

a) Internal space

The chamber inside was idealized as a multiplace to provide individual, comfortable and safe space to several small animals or as a monoplace chamber to fit an animal weighting up to $15 \mathrm{Kg}$.

\section{b) Cage size}

In order to allow a simultaneous treatment of several animals, the cage was projected and molded with acrylic drawers with interchangeable thick partition walls and covers, with small perforations for circulation of the gases (Figure 1 - left). The cut of acrylic plates, as well as the perforations, were carried through with laser equipment to prevent cutting surfaces that could wound the animals. The cages were projected with $150 \mathrm{~mm}$ in height, $280 \mathrm{~mm}$ in width and $690 \mathrm{~mm}$ in length.

\section{c) Number of animals}

In accordance to the divisions of the cages, there is enough space to the number of the animals in each session as follows: twenty mice, ten rats/hamsters, six rabbits, four cats, a dog, a swine. The minimum and maximum numbers depend on the race, weight, and age of the animal. The chamber is able to storage different kinds of animals of different sizes at the same time.

\section{Engineering and biological tests}

The final project (blueprints, drawings, and technical materials description) was submitted to the joint evaluation of the designer and the staff charged with the execution. The execution was in charge of a Brazilian company specialized in metallurgy and vessels of pressure. The special tests were performed for checking the adequacy of the pressurization valves, safety valve in case of extreme pressurization, defects of sealant device, regulation and check up of gases flow (compressed air and oxygen). To certify the security of the chamber, all the equipment and its accessories were tested and approved by companies of engineering and laboratories qualified by the Brazilian National Metrology Institute, Industrial Standardization and Quality (Instituto Nacional de Metrologia, Normalização e Qualidade Industrial $)^{14}$. Once the chamber was ready and complying with the standards of security of civil construction, it was placed in the Regional Integrated University - URI - Campus of Erechim (RS - Brazil). The facilities were exhaustedly tested: the electric devices were verified, and so were the gas flow and slide test for acrylic cages. Finally, the chamber was tested, with rats, in lots of different sizes followed by the evaluation of their behavior under hyperbaric conditions.

\section{Results}

With the partnership of an engineer, medical and veterinary staff, a safe and reliable hyperbaric chamber was built in steel carbon, like a tube with a fixed and elliptic rear and a mobile and plain frontal door with an acrylic window to observe the animal behavior during the experience period. It has the shape of a cylinder leaked with internal diameter of $50.5 \mathrm{~cm}$, length of $83.0 \mathrm{~cm}$ and walls thickness of $4.78 \mathrm{~mm}$. The frontal cover (in aluminum 5052) has $25.0 \mathrm{~mm}$ of thickness and with "O'ring" (sealant ring) for gas escape impairment, hinge by a system of closing for two screws, settled for rabbet, that promote the sealant air-tight of the set (Figures 2 and 3).

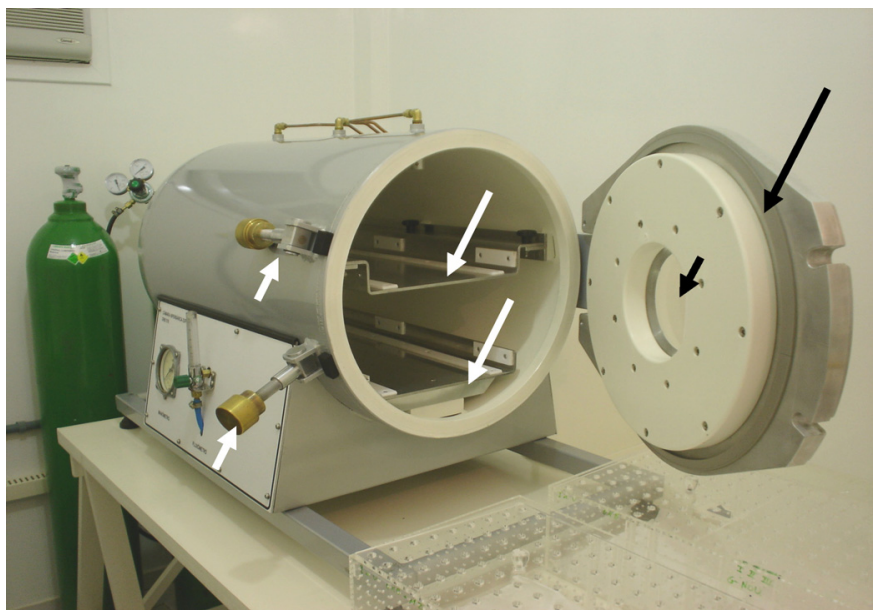

FIGURE 2 - Frontal view of the hyperbaric chamber showing the cover (long black arrow) with acrylic viewfinder (short black arrow), security latches (short white arrows) and internal thick partition upper/lower walls (long white arrows) 


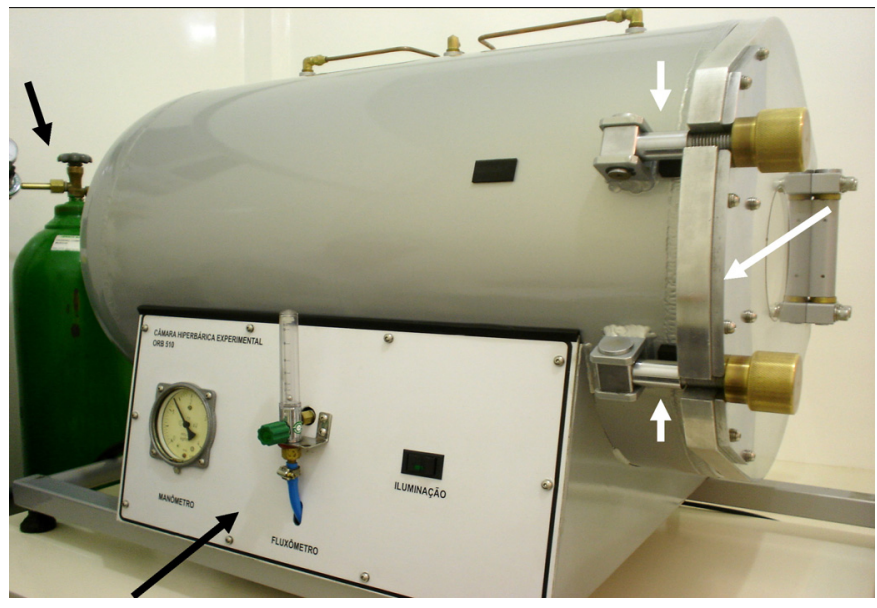

FIGURE 3 - Lateral view of the hyperbaric chamber showing the cover (white long arrow) closed with security latches (short white arrows) and the control panel (long black arrow). In the posterior part, the oxygen cylinder is distinguished (short black arrow)

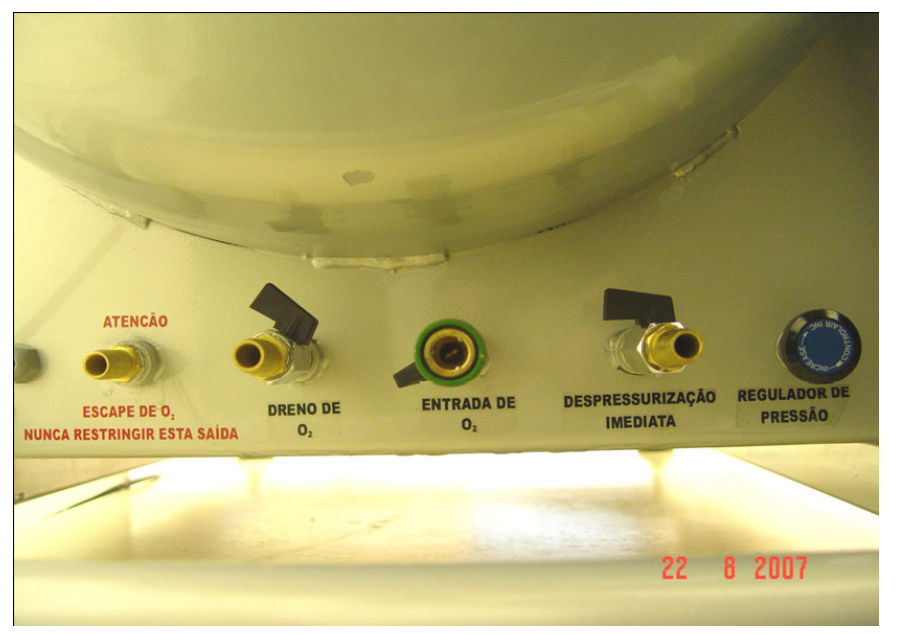

The chamber weighs about one hundred and sixty kilograms, has internal volume of one hundred and fifty liters. In the posterior extremity valves of entrance and exit of oxygen, oxygen drain and regulating valve of pressure were installed (Figure 4, top-left). The chamber pressure is controlled by an air pressure regulator (ControlAir Inc. - Type 100 Precision Air Pressure Regulator model) that was installed in the frontal panel (Figure 4, bottom). For entrance and exhaustion of gases, pipes were installed in the left lateral of the chamber as well as in the ceiling. The safety valve for cases of extreme pressurization is to the left and the manometer and fluximeter are situated to the right of the chamber. The fluximeter is in charge of regulating the rate of air renewal in the interior of the chamber for controlling the volume of oxygen that leaves the chamber (Figure 4 bottom).

In the interior of the cylinder, two horizontal thick partition walls were installed to act as a support for the acrylic cages. The central thick partition wall is removable to allow the entrance of bigger animals (Figure 5).



FIGURE 4 - Posterior view (top - left) of the hyperbaric chamber with the escape valve, the drain and the entrance of oxygen, depressurization valve and pressure controller. On the top-right side, the connected hardwired nets. - Detail of the frontal panel with the manometer and fluximeter for renewal of the oxygen (bottom) 


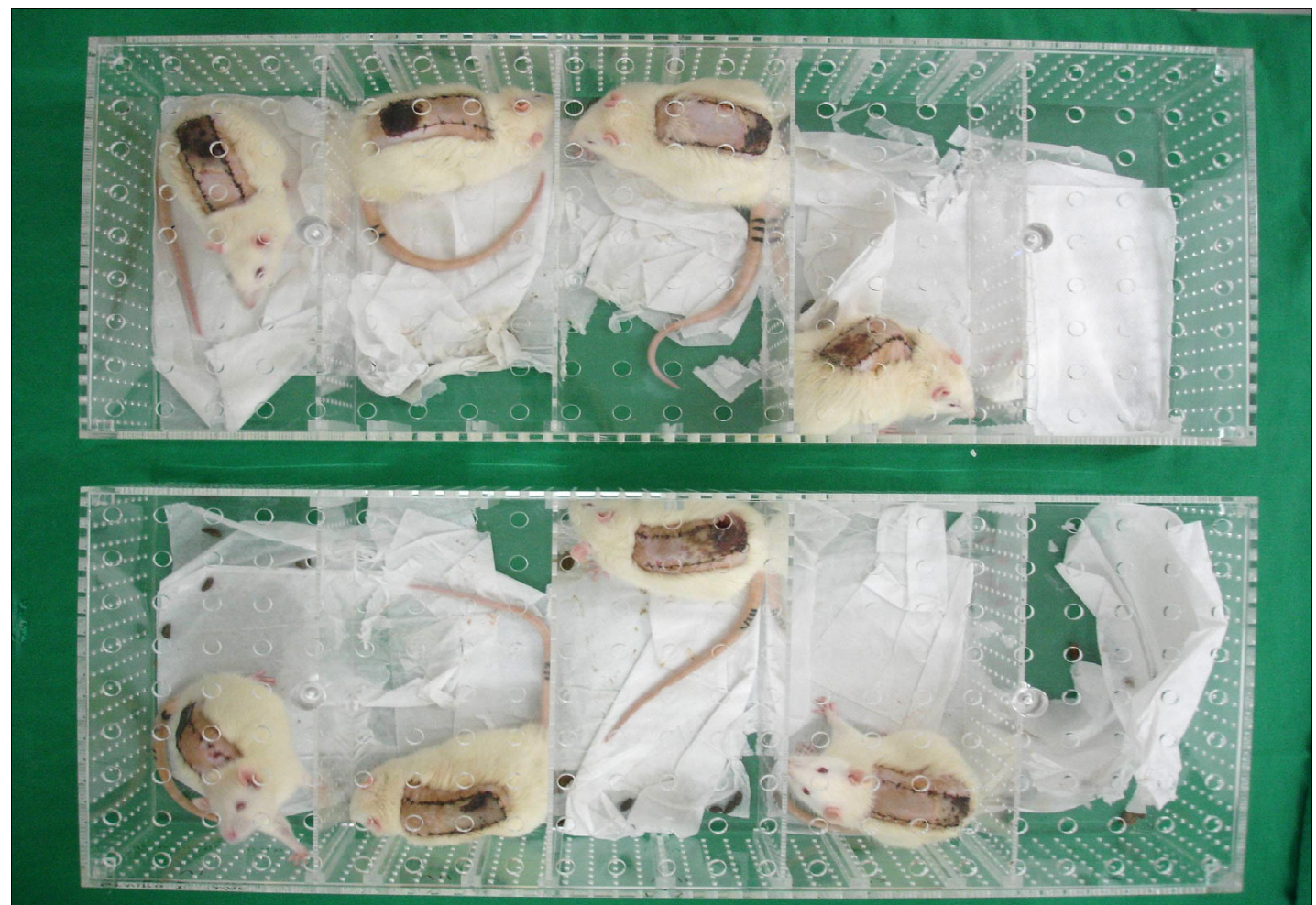

FIGURE 5 - Top view of the acrylic drawers with the rats in separate compartments, ready to be placed in the shelves in the interior of the chamber

\section{Discussion}

The hyperbaric chamber is equipment capable to keep an animal in adequate vital conditions in an environment above one atmosphere of pressure with compressed air or of medicinal oxygen, for a variable period until its returns to the normobaric conditions ${ }^{19}$.

The beginning of the therapeutic application of hyperbaric oxygen was in the $1950 \mathrm{~s}$, and since then it has been used in clinical and experimental research. The oxygen can be supplied through masks, when the patient is in compressed air chambers, or for the proper environment of pressurization. Initially, the use of the HBO was exclusive to the diving professionals for the prevention of decompression illness and traumatic embolism. At first, chambers were projected to hold more than three or four workers and the pressurization was done through compressed air and the oxygen was administered through a mask. In 1961, Boerema related the construction of a surgical room under high atmospheric pressure ${ }^{20}$. Baffes et al. ${ }^{21}$ related the use of a metal chamber fitted for only one patient per session, using pure oxygen for pressurization.

With the advance of technology and the wide knowledge about the hyperbarism, some norms were established to regulate the construction, maintenance, and use of hyperbaric chambers. The great majority of them is to be used in human beings and is unusual to verify references in biomedical literature on hyperbaric chambers especially focused on animal uses (veterinarian or experimentation animals).
There was only one reference to a chamber, made in acrylic material for use in rodents (rats and mice) ${ }^{22}$. Such equipment, used by other researchers ${ }^{23-26}$, even though it has shown effectiveness for experimental application, presents limitations in the number of animals that can be used in each session and is only suitable for small animals. From the technical point of view the possibility of the material to present fatigue in a precocious way and the instability of the different parts fixed by screws, lead to the high risk of inadequate pressurization (escape of gas) and even the explosion of the chamber.

The conception of this work was to make possible the construction of a hyperbaric chamber that was at the same time safe, which could support a bigger number of animals and could be used in animals of different sizes.

The results of the tests showed the security and reliance of the chamber, which supported pressures of up to 4 ATM (four absolute atmospheres) without gas escape through the sealant areas. Therefore, it has surpassed the security limits established by the legal standards for the current use of HBO, which dictates the use of up to 3 ATM (three absolute atmospheres) ${ }^{1}$.

The equipment showed an extreme malleability of use with different species and different numbers of animals. The tests showed its efficiency to storage in each session up to twenty mice or ten rats, up to two rabbits, one swine, or one dog. The acrylic window allowed the observation of the animals during all experiment, following their behavior variation and allowing the interruption of the session if necessary. 
The equipment management is simple and requires a training of about forty hours in normal conditions and emergencies. The equipment provides a safety valve for the escape of gases in case of malfunction in the pressurization. Luminous or sonorous alarms can be adapted to the control panel.

The possibility of using the equipment on a greater number of animals per session brings an operational advantage to diminish the costs with the gases, electric energy and improves the performance of the medical and paramedical staff.

To the scientific research, it offers the possibility of homogeneous samples mainly in the periods of HBO and in the number of sessions. In a simple session, different groups of animals can be displayed to the same conditions of treatment and in another session equal groups of animals can be displayed to different conditions of HBO. The internal divisions in individual cages created multiplace spaces where the animals can remain awake and comfortable, without risk of aggression, cannibal behavior, or undesirable mating.

The acrylic drawers are easy to slide in and out and are easy to be cleaned. The drawers can be built or be adapted to specific projects or specific animal species individually.

This chamber for animal use has similar features to those used for human beings. Its maintenance is low cost and must be done preventively after every one hundred hours of use.

The adapted chambers ("home made") do not follow strict standards of security, putting in risk the animals and even the operators of the equipment. Moreover, it is not reliable at times they cannot reach steady and reliable pressure levels. The use of chambers for human beings generally brings restriction for animal use and they depend on idle time of the equipment and schedules, when they do not clash with the routine of normal attendance. There are also the logistic implications of transportation and preservation of the animals, submitted to stress by the change of environment.

The equipment and facilities are an upgrade in our research laboratories and can improve our further works in our research baseline ${ }^{23-26}$.

This proposed chamber comes to fill a gap necessary to the development of the research in hyperbaric oxygenation, just when its indication for treatment of new pathological situations is increasing, mainly in ischemia and reperfusion of organs and tissues. On the other hand, even in the established situations of consensus on its effectiveness, some points need to be standardized and validation protocols must be established. The research in animals in reliable and similar equipment to the ones of human use is a basic part in these situations.

\section{Conclusion}

The development of the project allowed the manufacture of a hyperbaric chamber to be used with animals (experimentation animals and veterinarian use) with security characteristics of comparable use and reliance to those used for the $\mathrm{HBO}$ in human beings.

\section{References}

1. MeSH - Medical Subject Headings [serial on line] 2007. Available in URL: http://decs.bvs.br.

2. Workman, WT. Hyperbaric chamber design and facility safety. In: Bakker DJ, Cramer FS. Hyperbaric surgery. EUA: Ed. Best Publishing Company; 2002. p.159-62.

3. Gammper TJ, Zhang F, Mofakhami NF. Beneficial effect hyperbaric oxygen on island flaps subjected to secondary venous ischemia. Microsurgery. 2002;22(2):49-52.

4. Kranke P, Bennett M, Roeckl-Wiedmann I, Debus S. Hyperbaric oxygen therapy for chronic wounds (Cochrane Review). Cochrane Database Syst Rev. 2004;(2):CD004123.

5. van Hulst RA, Haitsma J, Klein J, Lachmann B. Oxygen tension under hyperbaric conditions in healthy pig brain. Clin Physiol Funct Imaging. 2003;23(3):143-8.

6. Meller R, Rostain J, Luciano M, Chays A, Bruzzo M, Cazals Y, Magnam J. Does repeated hyperbaric exposure to 4 atmosphere absolute cause hearing impairment? Study in guinea pigs clinical incidences. Otol Neurotol. 2003;24(5):723-7.

7. Petre MP, Baciewicz AF, Tigan S, Spears RJ. Hyperbaric oxygen as a chemotherapy adjuvant in the treatment of metastatic lung tumors in rat model. J Thorac Cardiovasc Surg. 2003;125(1):85-95.

8. Abidia A, Laden G, Kuhan G, Johnson FB, Wilkinson RA, Renwick MP, Masson AE, McCollum TP. The role of hyperbaric oxygen therapy in ischemic diabetic lower extremity ulcers: a double-blind randomisedcontrolled trial. Eur J Vasc Endovasc Surg. 2003;25 (6):513-8.

9. Weiss DD, Stevens MD, Yan J, Lynch LK, Matloub SH. Hyperbaric oxygen: a means of decreasing ischemic epiphyseal damage in a pediatric rabbit model. J Hand Surg. 2000;25(1):159-65.

10. Franzco Hirst WL, Summers MP, Fanzca DG, Bancroft J, Franzco L. Controlled trial of hyperbaric oxygen treatment for alkali corneal burn in the rabbit. Clin Experiment Ophthalmol. 2004;32:67-70.

11. Phillips S, Kohn M, Baker D, Leest V, Gomez H, Mckinney P, Mcgoldrick J, Brent J. Therapy of brown spider envenomation: a controlled trial of hyperbaric oxygen, dapsone, and cyproheptadine. Ann Emerg Med. 1995;25(3):363-8.

12. Bellucci G. Breve storia della terapia iperbarica. Minerva Anestesiol. 1991;57:183-5.

13. Mesquita WP, Pedrosa Neto AH. Resolução no 1.457 de 15 de setembro de 1995. Conselho Federal de Medicina. Diário Oficial da União. Brasília, 19 de setembro de 1995, seção I, pt. 1, p 16.585.

14. Instituto Nacional de Metrologia Normalização e Qualidade Industrial. Available from URL: http://www.inmetro.gov.br.

15. Norma Regulamentadora (NR) 13 do Ministério do Trabalho Available in URL: http://www.mte.gov.br/legislacao/ normas_regulamentadoras/nr_13.asp. Acessed in 01/10/2007.

16. ANSI/ASME PVHO-1-1997, Safety Standard for Pressure Vessels for Human Occupancy, American Society of Mechanical Engineers, New York; 1997.

17. Health Care Facilities Handbook, 5th Edition, Burton R. Klein, Ed. National Fire Protection Association, Quiny, Massachusetts; 1999. 18. Standard for Health Care Facilities, NFPA 99, 2002 Edition, National Fire Protection Association, Quincy, Massachusetts, p.102-12. 19. Romanello E, Caione R, Colonna S, Gismondi A. Tecnologia hiperbárica. Minerva Anestesiol. 1991;57(5):289-300.

20. Boerema I. An operating room with high atmospheric pressure. Surgery. 1961;49:291-8.

21. Baffes TG, Agustsson MH, Ketola FH, Baffes CG, Parker D. Administration of hyperbaric oxygen in an individual high pressure chamber. Surgery. 1966;60(2):319-28. 
22. Lyra Pereira ML, Teles AP, Pereira Neto J. Câmara hiperbárica de acrílico para animais de pequeno porte. Acta Cir Bras. 2001;16(4):658-663. 23. Guimarães FA, Taha MO, Simões MJ, Fagundes DJ. Ischemiareperfusion of the small intestine and hyperbaric oxygen treatment: a morphologic study in rats. Transplant Proc. 2002;34(3):977-9.

24. Vidigal J, Fagundes DJ, Simões MJ, Oshima CTF, Odashiro NA, Simões. RS, Fagundes ATN, Montero EFS, Taha MO. Effect of different periods of hyperbaric oxygen on ischemia-reperfusion injury of rat skeletal muscle. Microsurgery. 2007;27(4):252-7.

25. Bertoletto PR, Fagundes DJ, Simões MJ, Oshima CTF, Montero EFS, Simões RS, Fagundes ATN. Hyperbaric oxygen therapy on the rat intestinal mucosa apoptosis caused by ischemia-reperfusion injury. Microsurgery. 2007;27(4):224-7.
26. Bertoletto PR, Fagundes DJ, Simões MJ, Oshima CTF. Effect of different periods of hyperbaric oxygen on ischemia-reperfusion injury of rat small bowel. Acta Cir Bras. 2008;23(1):11-5.

\section{Acknowledgments}

The authors thank Anna Carolina N. F. Martino and Maria do Carmo Negrini Fagundes for assistance with translation and formatting of the article.
Conflict of interest: none

Financial source: none

\section{Correspondence:}

Djalma José Fagundes

Rua Camé, 244, 33

03121020 São Paulo - SP Brazil

Phone: (5511)6604-3186

Fax: (5511)6604-3147

djfagundes.dcir@epm.br

\section{How to cite this article}

Rech FV, Fagundes DJ, Hermanson R, Rivoire HC, Fagundes ALN. A proposal of multiplace hyperbaric chamber for animal experimentation and veterinary use. Acta Cir Bras. [serial on the Internet] 2008 July-Aug;23(4). Available from URL: http:// www.scielo.br/acb

*Color figures available from www.scielo.br/acb 